\title{
In vitro anti-inflammatory, anti-diabetic and antioxidant potential of Cissus quadrangularis along with its orexigenic activity in Drosophila melanogaster
}

\author{
Sadiya Zaki \\ Department of Biotechnology, Indian Academy Degree College-Autonomous, Bangalore \\ (Karnataka), India \\ Chaithra M L \\ Department of Biotechnology, Indian Academy Degree College-Autonomous, Bangalore \\ (Karnataka), India

\section{Sonu Bansal} \\ Department of Biotechnology, Indian Academy Degree College-Autonomous, Bangalore \\ (Karnataka), India \\ Latha V \\ Department of Chemistry, Indian Academy Degree College-Autonomous, Bangalore \\ (Karnataka), India \\ Monika Bajpai \\ Department of Chemistry, Indian Academy Degree College-Autonomous, Bangalore \\ (Karnataka), India

\section{Malathi R} \\ Department of Life Sciences, Kristu Jayanti College (Autonomous), Bangalore (Karnataka), India \\ Sibi $\mathbf{G}^{*}$ \\ Department of Biotechnology, Indian Academy Degree College-Autonomous, Bangalore \\ (Karnataka), India \\ *Corresponding author. Email: gsibii@gmail.com
}

\section{How to Cite}

Zaki, S. et al. (2021). In vitro anti-inflammatory, anti-diabetic and antioxidant potential of Cissus quadrangularis along with its orexigenic activity in Drosophila melanogaster. Journal of Applied and Natural Science, 13(3), 962 - 969. https:// doi.org/10.31018/jans.v13i3.2835

\begin{abstract}
Plants with diverse pharmacological activities are actively being explored for human health. Cissus quadrangularis (L) has been reported to possess numerous phytochemicals and is used to relieve various disorders. The aim of the present study was to provide evidence of the diverse pharmacological activities in terms of orexigenic, anti-inflammatory, anti-diabetic and antioxidant activities of $C$. quadrangularis for further application in clinical development. The results revealed that inhibition of hemolysis was within the range of $8-9-25.6 \%$ at concentrations of $12.5-200 \mu \mathrm{g} / \mathrm{ml}$. Methanol extract of the stems exhibited porcine pancreatic $\alpha$-amylase (PPA) inhibition ( $\leq 0.05$ ) at concentrations of 0.25 and $0.30 \mathrm{mg} / \mathrm{ml}$. The glucose adsorption capacity of the plant was observed to be inversely proportional to the molar concentration of glucose. The higher food intake by Drosophila in food medium with plant extract was presumably related to the orexigenic property of $C$. quadrangularis. Protease activity of the stem extract revealed total activity $975 \mathrm{U} / \mathrm{ml}$ and specific activity as $3768 \mathrm{U} / \mathrm{mg}$. The absorbance of the plant in reducing power assay was between 0.91 and 1.85 . The highest total antioxidant activity of $67.2 \mu \mathrm{g} \mathrm{TE} / \mathrm{g}$ was observed and the hydroxyl radicals scavenging activity was observed in a dose-dependent manner. The results provided supporting data that $C$. quadrangularis may contain active compounds useful in treating anti-inflammatory, anti-diabetic disorders.
\end{abstract}

Keywords: Antioxidant, Appetite stimulant, Cissus quadrangularis, Orexigenic

\section{INTRODUCTION}

Poor appetite is associated with essential nutrient deficiencies, and appetite stimulants' use is limited due to their side effects (Howard et al., 2019; Harrison et al., 2019; Levitt and O'Neil, 2018 and Homnick et al., 2004). Bioactive compounds from plants are used in treating digestive system illnesses. Hormones like 
ghrelin and some phytochemicals like gentiopicroside, tetrahydrocannabinol, linalool promote appetite, thus increase food intake (Kola et al., 2008; Nematy et al., 2013 and Azadbakht et al., 2020). However, understanding the dosage and side effects is crucial to provide safe and effective treatment. Further, treatments targeting appetite regulation have thus far limited clinical success.

The production of inflammatory mediators is a defense mechanism of the host, but its excessive production may lead to chronic diseases (Oguntibeju, 2018). Suppression of inflammatory reactions using steroids, nonsteroid and immunosuppressants are associated with adverse effects (Ghasemian et al., 2016). Plants with anti-inflammatory effects are reported to exhibit low or no side effects. Uncontrolled diabetes leads to morbidity and /or mortality and the use of synthetic drugs alongside insulin fail to reverse the course of diabetic complications though they are main route for controlling diabetes (Rao et al., 2010). Plant-derived active principles have established their role in treating diabetes, thus serving as an alternative source of anti-diabetic agents (Rizvi and Mishra, 2013, Salehi et al., 2019). Further, plants with antioxidant potential can be utilized for lowering blood glucose levels (Sekhon-loodu and Rupasinghe, 2019).

It is worth noting that plants have significantly fuelled drug development, and identifying potential plants with active principles for multiple disorders is much needed. Cissus quadrangularis is a tropical climbing shrub of Vitaceae family used in many parts of the world. This plant is rich in flavonoids, triterpenoids, stilbene derivatives and phytosterols with antioxidant potential, but more studies are needed to clarify pharmacological mechanisms of action. Bioactive components of $C$. quadrangularis have been used for cancer, obesity, antioxidant, anti-inflammatory disorders (Chatree et al., 2021; Siddiqui et al., 2021; Sundaran et al., 2020; Zaki et al., 2020; Stohs and Ray, 2013; Srisook et al., 2011). The plant also has hypoglycemic and anti-glycation activity (Chaudhari et al., 2013; Lekshmi and Mini, 2013). Phytochemical analysis of the plant revealed the presence of quercetin and resveratrol (Syed et al., 2021). Based on the aforementioned pharmacological activities of this plant, the present study investigated the effect of C. quadrangularis on food intake in Drosphila melanogaster. In addition to its orexigenic activity, antiinflammatory, anti-diabetic and antioxidant assays were performed to explore its collective pharmacological activities.

\section{MATERIALS AND METHODS}

\section{Preparation of plant extract}

Fresh stems of $C$. quadrangularis were air-dried in blotting paper and defatted with petroleum ether. The defat- ted powder was extracted with $80 \%$ methanol in a soxhlet apparatus for $48 \mathrm{hrs}$. The obtained extract was concentrated under reduced pressure and used for antioxidant assays.

\section{Antioxidant assays \\ Measurement of reducing Power}

The $\mathrm{Fe}^{3+}$-reducing power of the extract was determined by a standard method (Fejes et al., 2000). Different concentrations $(0-1.0 \mathrm{mg} / \mathrm{ml})$ of the extract were mixed with equal volume of $0.2 \mathrm{M}$ phosphate buffer $(\mathrm{pH} 6.6)$ and $0.1 \%$ potassium hexacyanoferrate, followed by incubation for $20 \mathrm{~min}$ at $50^{\circ} \mathrm{C}$. After incubation, the reaction was terminated with $0.5 \mathrm{ml} 10 \%$ TCA. Then, $1 \mathrm{ml}$ reaction mixture was diluted with $1 \mathrm{ml}$ distilled water followed by the addition of $0.1 \mathrm{ml} \mathrm{FeCl}{ }_{3}$ solution $(0.01 \%)$. The reaction mixture was left for $10 \mathrm{~min}$ at room temperature and the absorbance was measured at $700 \mathrm{~nm}$ against an appropriate blank solution. Butylated hydroxy toluene (BHT) was used as a standard.

\section{Total antioxidant activity}

The total antioxidant activity of plant extract was estimated by phosphomolybdenum assay (Jayaprakasha et al., 2002). Methanolic extract of $C$. quadrangularis in different concentrations ranging from 100-500 $\mathrm{g} \mathrm{m} \mathrm{ml}^{-1}$ were added to each test tube individually containing 3 $\mathrm{ml}$ of distilled water and $1 \mathrm{ml}$ of molybdate reagent solution. The tubes were incubated at $95^{\circ} \mathrm{C}$ for $90 \mathrm{~min}$ followed by normalization to room temperature for 20 $30 \mathrm{~min}$ and the absorbance of the reaction mixture was measured at $695 \mathrm{~nm}$ using a UV-Vis spectrophotometer. The total antioxidant activity was as expressed as $\mu \mathrm{g}$ equivalents of $\alpha$-tocopherol $(\mu \mathrm{g} \mathrm{TE} / \mathrm{g})$.

\section{Hydroxyl radicals scavenging assay}

The hydroxyl radical scavenging assay was performed using a standard protocol method (llavarasan et al., 2005). In a final volume of $1 \mathrm{ml}$, various concentrations of the test sample or reference compound was mixed with 2-deoxy-2-ribose (2.8 mM); $\mathrm{KH}_{2} \mathrm{PO}_{4}-\mathrm{KOH}$ buffer $\left(20 \mathrm{mM}, \mathrm{pH}\right.$ 7.4); $\mathrm{FeCl}_{3}(100 \mu \mathrm{M})$; EDTA $(100 \mu \mathrm{M})$; $\mathrm{H}_{2} \mathrm{O}_{2}(1.0 \mathrm{mM})$; ascorbic acid $(100 \mu \mathrm{M})$ and incubated for $1 \mathrm{~h}$ at $37^{\circ} \mathrm{C}$. $0.5 \mathrm{ml}$ of the reaction mixture was added to $2.8 \%$ TCA, followed by $1 \%$ TBA and incubated at $90^{\circ} \mathrm{C}$ for colour development and the absorbance was measured at $532 \mathrm{~nm}$ against an appropriate blank solution. The scavenging activity on hydroxyl radical was calculated as follows.

Hydroxyl Radical Scavenging activity $(\%)=\left\{\left(1-A_{532}\right.\right.$ Sample $) / A_{532}$ Control $\} \times 100 \quad$..Eq. 1

\section{Anti-inflammatory activity} Inhibition of protein denaturation method

Protein denaturation assay was done according to the method of Mizushima et al. (1968). Different concentra- 
tions of the stem extract were added to $1 \%$ bovine serum albumin solution. The mixture was incubated in a waterbath $\left(37^{\circ} \mathrm{C}\right.$ for $\left.20 \mathrm{~min}\right)$ and the reaction mixture was heated at $57^{\circ} \mathrm{C}$ for $20 \mathrm{~min}$ and was allowed to cool. The turbidity of the samples was measured at $660 \mathrm{~nm}$ and percent inhibition of protein denaturation was calculated as follows:

Protein denaturation inhibition $(\%)=\left(1-\mathrm{A}_{660}\right.$ Sample/ A $_{660}$ Control) $\times 100$ ..... Eq.2

\section{Red blood cell membrane stabilization test}

Anti-inflammatory activity of $C$. quadrangularis stem extract was evaluated by red blood cells membrane stabilization test. Blood sample collected from ICARIndian Veterinary Research Institute, Bengaluru was diluted to $10 \% \mathrm{v} / \mathrm{v}$ with saline. Plant extract $(1 \mathrm{ml})$ was added to $1 \mathrm{ml}$ of red blood cell suspension and incubated at $56^{\circ} \mathrm{C}$ for $30 \mathrm{~min}$. The reacted mixture was centrifuged at $2500 \mathrm{rpm}$ for $5 \mathrm{~min}$ and the absorbance of the supernatant was measured at $560 \mathrm{~nm}$. Saline was used as a control for the experiment and the membrane stability percentage was calculated using the following formula (Sadique et al., 1989).

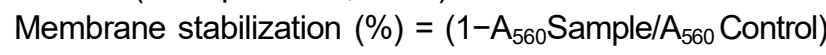
$\times 100$ .....Eq.3

\section{$\alpha$-amylase inhibitory assay}

In vitro a-amylase of $C$. quadrangularis was determined by preparing various concentrations of the extract in DMSO. Substrate was prepared by adding $0.5 \mathrm{M}$ tris$\mathrm{HCl}$ buffer ( $\mathrm{pH} \mathrm{6.9)}, 0.01 \mathrm{M} \mathrm{CaCl}_{2}(0.2 \mathrm{ml})$ and starch (2 mg). The substrate mixture was boiled for 5 mins and different concentrations of the plant extract $(0.2 \mathrm{ml})$ was added to each tube followed by porcine pancreatic amylase $(0,1 \mathrm{~mL}$ in Tris- $\mathrm{HCl}$ buffer $(2$ units/ $\mathrm{mL})$. The reaction mixture was incubated at $37^{\circ} \mathrm{C}$ for $10 \mathrm{~min}$ and the reaction was stopped by adding $50 \%$ acetic acid $(0.5 \mathrm{ml})$ followed by centrifugation at $3000 \mathrm{rpm}$ for 5 mins. Absorbance of the supernatant was measured at $595 \mathrm{~nm}$ using a spectrophotometer. Acarbose was used as positive control and the a-amylase inhibitory activity was calculated using the following formula (Tamil et al., 2010).

$\%$ a-amylase inhibition $=\left\{\left(\mathrm{A}_{595}\right.\right.$ control- $\mathrm{A}_{595}$ Sample $) /$ $\mathrm{A}_{595}$ Control\} $\times 100$ ......Eq.4

\section{Glucose uptake by yeast cells}

Suspension of commercial Baker's yeast was prepared in distilled water $(10 \% \mathrm{w} / \mathrm{v})$, centrifuged and the supernatant was used for glucose uptake studies (Cirillo, 1962). Various concentrations of $C$. quadrangularis extract were added with $1 \mathrm{ml}$ of glucose solution (5-25 $\mathrm{mM}$ ) in test tubes and incubated at $37^{\circ} \mathrm{C}$ for 10 mins. This was followed by the addition of $100 \mu$ of yeast suspension into each tube and further incubated at $37^{\circ}$ C for $60 \mathrm{~min}$. After incubation, the tubes were centri- fuged at $5000 \mathrm{rpm}$ for 5 mins and the glucose was estimated in the supernatant using a Spectrophotometer at $520 \mathrm{~nm}$ with metronidazole as standard. The following formula was used to calculate the percent increase in glucose uptake by yeast cells.

$\%$ increase in glucose uptake $=\left\{\left(A_{520}\right.\right.$ control $-A_{520}$ Sample) $/ A_{520}$ Control\} $\times 100$ ....Eq. 5

\section{Orexigenic studies}

\section{Fly husbandry and culture media}

Wild type Drosophila melanogaster were housed and maintained at $25^{\circ} \mathrm{C}, 65 \%$ humidity, on a $12 \mathrm{~h}$ : $12 \mathrm{~h}$ light: dark cycle in culture bottles. The standard growth medium consisted of yeast $(2 \mathrm{~g})$, sucrose $(10 \mathrm{~g})$, cornmeal $(3.3 \mathrm{~g})$, propionic acid $(1 \mathrm{~g})$, agar (1 g), ampicillin (0.01 $\mathrm{g}$ ), chloramphenicol (0.002 g), autolyzed yeast powder $(20 \mathrm{~g})$ and $2.5 \%(\mathrm{w} / \mathrm{v})$ blue food dye (F D \& C blue dye no.1) in distilled water $(100 \mathrm{ml})$. For the orexigenic experiments, C. quadrangularis extract was added to the growth medium at $0.5 \%(\mathrm{w} / \mathrm{v})$.

\section{Food intake assay}

For the quantification of food intake, 10 flies were collected from control and experimental bottles using light chloroform anaesthesia, homogenized in $1 \mathrm{ml}$ of phosphate buffer $(0.1 \mathrm{M})$ and diluted to $1 \mathrm{ml}$. Homogenization was performed quickly to prevent the interference of eye pigments. The homogenized suspension was centrifuged at $10000 \mathrm{rpm}$ for 10 mins. The absorbance of the supernatant was then measured at $625 \mathrm{~nm}$ in a UV-Vis Spectrophotometer (Edgecomb et al., 1994). Food-dye medium without plant extract was used as control and absorbance values were converted to volumes of medium consumed by interpolation from standard curves of pure dyes (Shell et al., 2018).

\section{Extraction of protease}

Freshly collected stems of $C$. quadrangularis were rinsed with distilled water and air-dried in blotting paper. Ten grams of the sample was extracted with Tris$\mathrm{HCl}$ buffer (50 mM; pH-7.2) containing ascorbic acid $(0.01 \% \mathrm{w} / \mathrm{v})$, poly(Vinylpolypyrrolidone) $(0.1 \% \mathrm{w} / \mathrm{v})$ in the ratio of $1: 3$. The mixture was filtered, centrifuged at $10,000 \mathrm{rpm}$ for $15 \mathrm{~min}$ at $4^{\circ} \mathrm{C}$ and the supernatant was used as source of protease enzyme.

\section{Estimation of protease activity}

The amount of protease present in the C. quadrangularis extract was determined by mixing the extract with $0.5 \mathrm{ml}$. of tris-HCl buffer $(50 \mathrm{mM}$; $\mathrm{pH} 7.2)$ and $0.5 \mathrm{ml}$ of casein $(2 \% \mathrm{w} / \mathrm{v})$ dissolved in citrate phosphate buffer (50 mM; pH 6.8). The reaction mixture was incubated at $37^{\circ} \mathrm{C}$ for $1 \mathrm{~h}$ and the reaction was terminated by with $1 \mathrm{ml}$ of $10 \%(\mathrm{w} / \mathrm{v})$ ice-cold TCA. Centrifugation of the mixture was done at $5000 \mathrm{rpm}$ for 5 mins to remove unhydrolyzed casein substrate and the supernatant 
was mixed with $2.5 \mathrm{ml}$ of the reagent containing $2.9 \%$ $\mathrm{Na}_{2} \mathrm{CO}_{3}$ and $0.3 \mathrm{~N} \mathrm{NaOH}$ was added followed by the addition of $0.75 \mathrm{ml}$ of Folin Ciocalteu's phenol reagent (Folin phenol: distilled water ; 1:3). The samples were incubated at $37^{\circ} \mathrm{C}$ for $20 \mathrm{~min}$ and read at $650 \mathrm{~nm}$ using a spectrophotometer. A standard curve constructed with tyrosine was used to construct the standard curve. One unit of protease activity was defined as the amount of enzyme that liberates $1 \mu \mathrm{mol}$ of tyrosine equivalent per minute under the assay conditions (McDonald and Chen, 1965).

\section{RESULTS AND DISCUSSION}

The present study observed that reducing power ability of the methanolic stem extract of $C$. quadrangularis was comparable to that of BHT. At $50-300 \mu \mathrm{g} / \mathrm{ml}$ concetration, the absorbance of the extract and ascorbic acid were $0.76-1.63$ and $0.91-1.85$ respectively as shown in Fig. 1. Reducing power of $C$. quadrangularis is associated with its phytochemicals (Vijayalakshmi et al., 2013 ). Nabavi et al., (2009) indicated that $\mathrm{Fe}^{3+}$-reducing power is mainly associated with the phenolic antioxidant activity of plants while investigating Pyrus boissieriana and Diospyros lotus extracts.

Total antioxidant activity of $C$. quadrangularis extracts expressed as the number of equivalents of a-tocopherol was obtained from the calibration curve. The phosphomolybdate method is a quantitative method to express the total antioxidant activity. At $300 \mu \mathrm{g} / \mathrm{ml}$ concentration, the highest total antioxidant activity (67.2 $\mu \mathrm{g} \mathrm{TE} / \mathrm{g}$ ) was observed. However, the antioxidant potential was lower than the standard BHT $(82.3 \mu \mathrm{g}$ TE/g) (Fig. 2).

Hydroxyl radicals produced from Fenton reaction degrade the deoxyribose. Measuring the inhibition of deoxyribose degradation indicated the hydroxyl radical scavenging activity of plant extract. C. quadrangularis extract, when added to the reaction mixture, scavenged

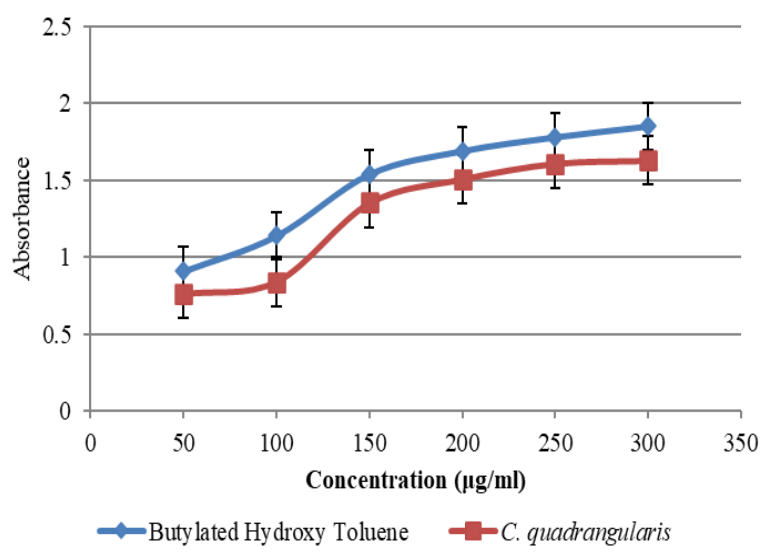

Fig. 1. Reducing power activity of C. quadrangularis. hydroxyl radicals in a dose-dependent manner. The scavenging activity was comparable with the standard, quercetin and the activity is shown in Fig. 3 . When the concentration of plant extract was more than $200 \mu \mathrm{g} / \mathrm{ml}$, the scavenging effect was more than $60 \%$. Similar hydroxyl radical scavenging inhibition activities were observed at 200 and $400 \mu \mathrm{g} / \mathrm{ml}$ concentrations in an earlier study using aerial parts of $C$. quadrangularis extracted in ethanol and methanol (Dhanasekaran, 2020). In the present study, $80 \%$ methanol was used to prepare stem extracts of $C$. quadrangularis and the scavenging of hydroxyl radicals was in line with antioxidant activity of aerial parts of the same plant indicating that antioxidant potential of stems. Therefore, selection of the most appropriate plant part is required while investigating its bioactivity instead of the whole plant as it was proven in this study that stem of the same plant had exhibited similar free radical scavenging activity when compared to the aerial parts extracted with the same solvent. Based on the results obtained in this study, C. quadrangularis stem extract is a good source of antioxidants as determined through different assays. The antioxidant activities were comparable to the standard drugs such as $\mathrm{BHT}$ and quercetin in terms of inhibition and free radical scavenging activities.

C. quadrangularis stem extract was able to inhibit RBC hemolysis and protein denaturation in a concentration dependent manner. Inhibition of hemolysis was within the range of $8-9-25.6 \%$ at concentrations of $12.5-200$ $\mu \mathrm{g} / \mathrm{ml}$ (Fig. 4). Protein denaturation of the extract was within the range of $28.2-61.2 \%$ and the ability of the extract to prevent protein denaturation is attributed to its anti-inflammatory properties. Membrane destabilization property of the extract could be associated with interference of release of inflammatory mediators and prevention of hypotonicity induced lyses of RC membrane as well as lysosomal constituents (Iwueke et al., 2006; Chou., 1997). Anti-inflammatory activities of roots and stem extracts of $C$. quadrangularis is reported by Shadmani et al., (2018) and the activity is involved with in-

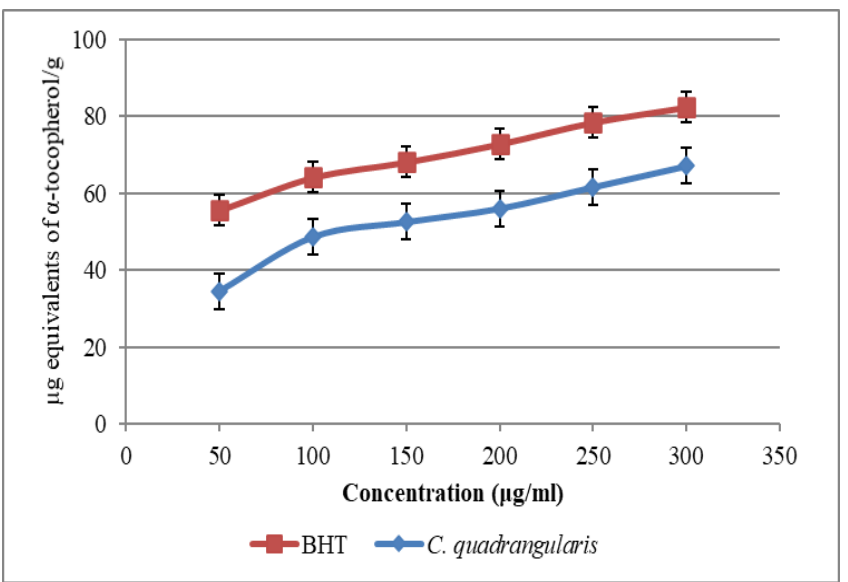

Fig. 2. Total antioxidant activity of C. quadrangularis. 
Zaki, S. et al. / J. Appl. \& Nat. Sci. 13(3), 962 - 969 (2021)

duction of heme oxygenase enzyme (Srisook et al., 2011).

Alpha-amylase inhibitors prevent the hydrolysis of starch thereby reducing the postprandial blood glucose levels (Gulati et al., 2012). Alpha amylase inhibition potential of $C$. quadrangularis is shown in Fig. 5. The inhibition percentage of the enzyme was based on the concentration of the extract in a dose-dependent manner. Methanol extract of $C$. quadrangularis stems exhibited moderate porcine pancreatic $\alpha$-amylase (PPA) inhibition $(p \leq 0.05)$ at concentrations of 0.25 and $0.30 \mathrm{mg} /$ $\mathrm{ml}$. Fig. 6 highlights the glucose adsorption capacity directly proportional to the glucose concentration observed in this study. The plant extract has promoted the uptake of glucose across the plasma membrane of yeast cells. The glucose adsorption capacity of the $C$. quadrangularis was observed to be inversely proportional to the molar concentration of glucose. Glucose adsorption by both plant extract and standard drug was reduced with an increased glucose concentration. The results showed that $C$. quadrangularis stem extract could bind glucose effectively, suggesting its contribution in weakening the postprandial hyperglycemia. Salehi et al., (2019) reported that the anti-diabetic ef-

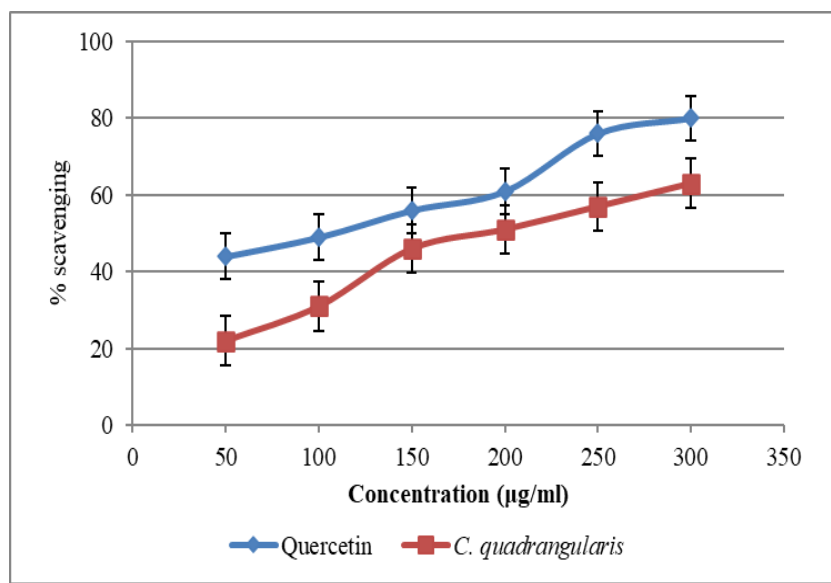

Fig. 3. Hydroxyl radical scavenging activity of $C$. quadrangularis.

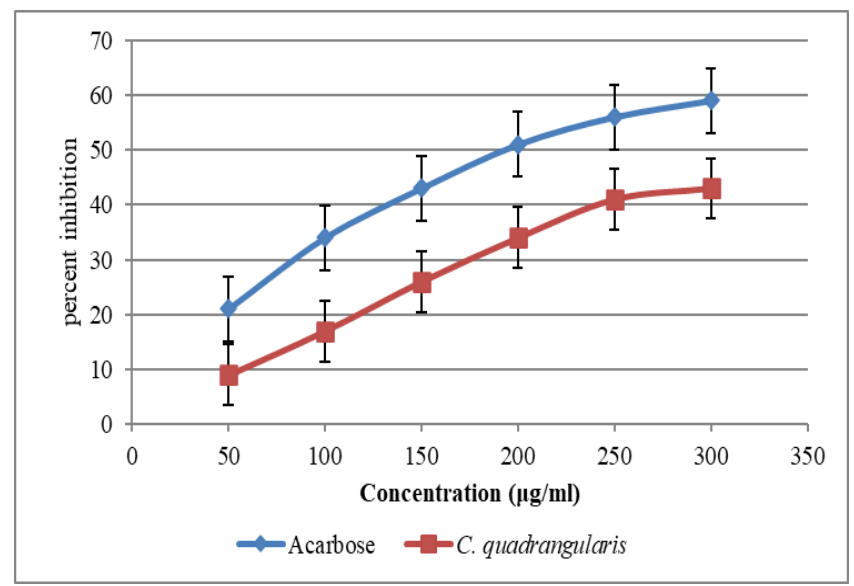

Fig. 5. Alpha-amylase inhibition of C. quadrangularis stem extract. fect of medicinal plants native to Asian countries is attributed to the phytochemical components of the plant extracts as observed in animal (alloxan/streptozotocin induced diabetic rats) and human (diabetic, prediabetic patients, type 2 diabetes mellitus subjects) models.

Drosophila exhibits similarities with mammals, which is suitable for nutritional studies (Staats et al., 2018). The goal of this present study was to develop and validate a simple, inexpensive method for determining appetite inducing activity of $C$. quadrangularis through food intake studies by Drosophila. Estimating food uptake by dye usage is easy, inexpensive and can be rapidly assessed by visual inspection. Food dyes added up to $2.5 \%$ concentrations do not affect the food intake by Drospohila (Deshpande et al., 2014). Blue dye remains within the digestive tract and passes out of the fly unaffected by gut $\mathrm{pH}$ and enzymes. Fig $7 \mathrm{a}$ and $7 \mathrm{~b}$ indicate Drosophila fed in food media with and without C. quadrangularis stem extract. Flies fed with $C$. quadrangularis extract exhibited more blue dye in their abdomen region revealing the more food intake influenced by orexigenic property of the plant. Similarly, flies fed food media without $C$. quadrangularis stem extract shown lesser blue dye uptake.The amount of food intake was

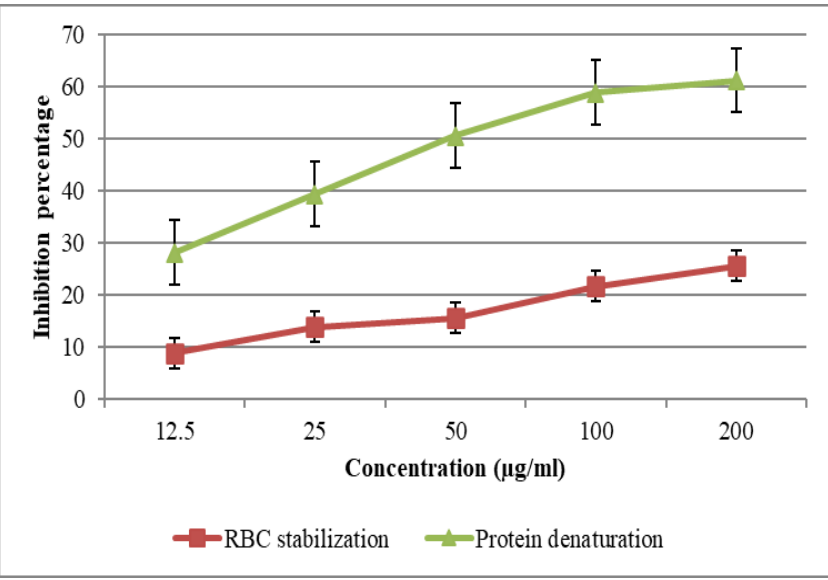

Fig. 4. Hemolysis inhibition activity of C. quadrangularis.

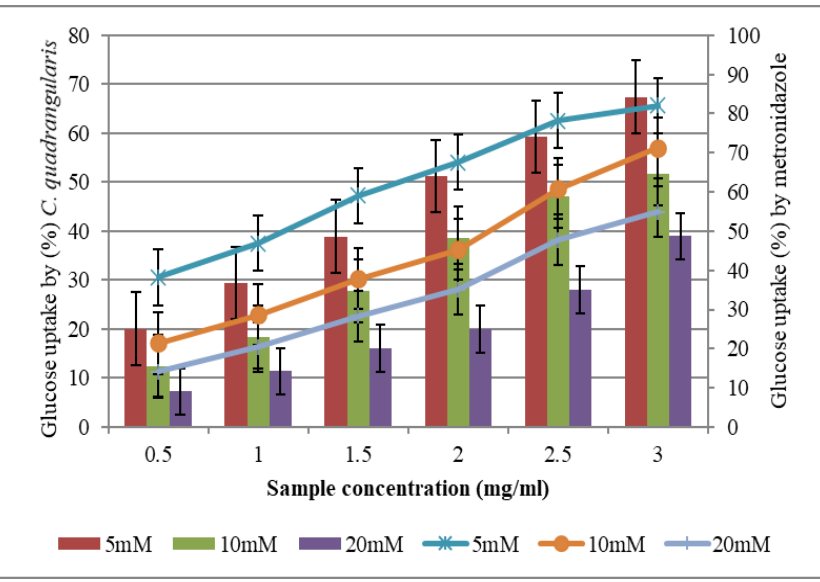

Fig. 6. Glucose adsorption assay using C. quadrangularis stem extract. 


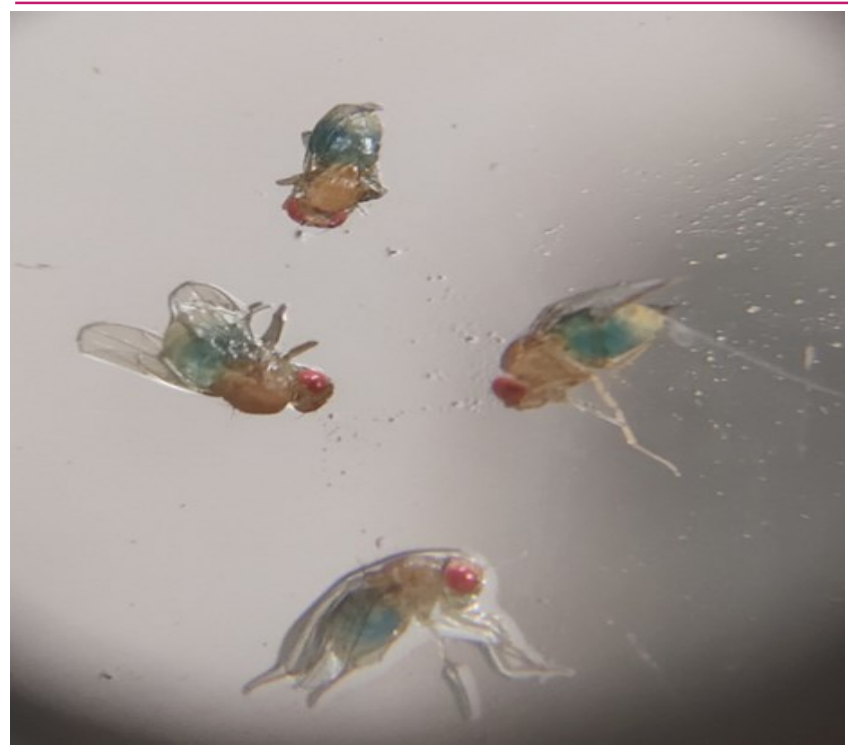

Fig. 7a. Drosophila fed in food media with C. quadrangularis extract showing orexigenic activity as indicated by intense blue dye.

measured by quantitating the dye via spectrophotometry (Fig. 8).

Proteases are present in plant tissues that hydrolyze protein into peptides and amino acids. Proteases from Pongamia pinnata, Wrightia tinctoria, Acalypha indica, Adhatoda vasica, Curcuma longa, Carica candamarcensis and Ananas comosus are used in pharmaceutical applications (Chinnadurai et al., 2018; Mello et al., 2008; Kelly, 1996). In this study, protease activity of C. quadrangularis stem extract revealed total activity as $975 \mathrm{U} / \mathrm{ml}$ and specific activity as $3768 \mathrm{U} / \mathrm{mg}$. Plant extracts with higher proteolytic activity $(>3000 \mathrm{U} / \mathrm{mg})$ have been used in traditional medicine for teating various disorders (Otsuki et al., 2010; Mello et al., 2008) and the presence of higher protease activity in C. quadrangularis stems as determined in this study reveals its pharmacological applications. In general, proteases from medicinal plants are preferred for industrial application as they do not require any co-factors (Asif-Ullah

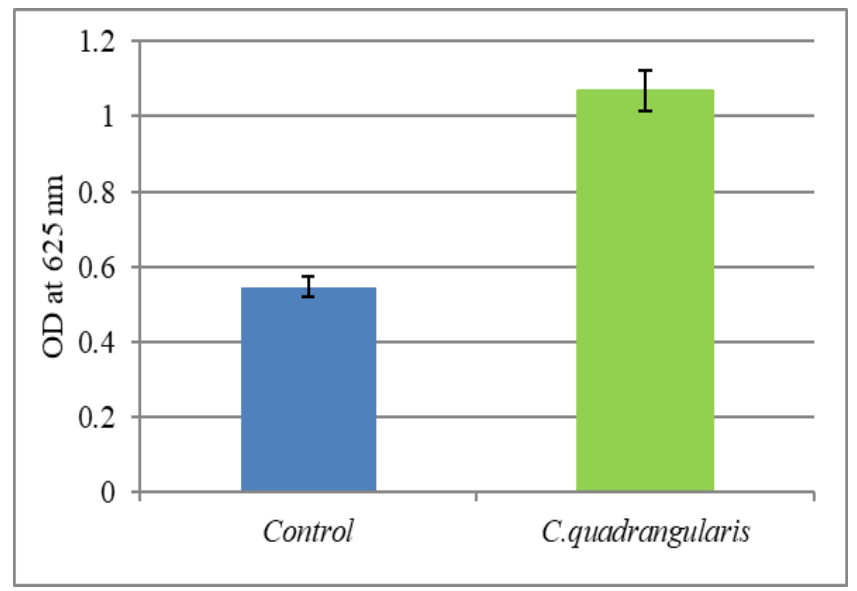

Fig. 8. Spectrophotometric quantitation of food dye intake by Drospohila in orexigenic assay.

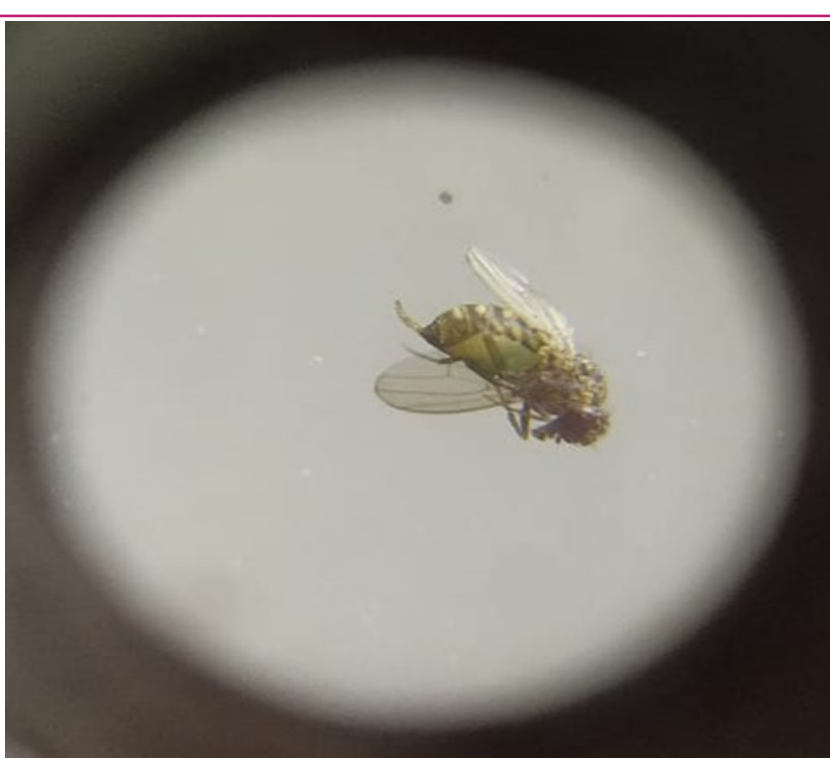

Fig. 7b. Drosophila fed in food media without C. quadrangularis extract showing lesser blue dye.

et al., 2006). Cysteine proteases were purified from $C$. quadrangularis by Muthu et al. (2017), and the safety of this plant in bone fracture treatment, including enhanced bone growth and anti-osteoporotic activities, were reported by Sawangjit et al. (2017).

\section{Conclusion}

This study indicated that Cissus quadrangularis had a positive effect on the food intake of Drosophila melanogaster. Future studies evaluating the effects of this plant on human appetite are warranted. The results provide supporting data that $C$. quadrangularis contain proteases and phenolic compounds and a-amylase inhibitors that are useful in treating anti-inflammatory, anti-diabetic disorders. However, purification of specific bioactive compounds and clarifying their pharmacological mechanisms of action is needed to treat various disorders by using this plant.

\section{Conflict of interest}

The authors declare that they have no conflict of interest.

\section{REFERENCES}

1. Asif-Ullah, M., Kim, K.S. \& Yu, Y.G. (2006). Purification and characterization of a serine protease from Cucumis trigonus Roxburghi. Phytochemistry, 67, 870-875. DOI: 10.1016/j.phytochem.2006.02.020

2. Azadbakht, M., Nayebii, E., Fard, R.E. \& Khaleghi, F. (2020). Standardization and formulation of an herbal appetite-stimulating drug from Gentiana olivieri. Journal of Herbal Medicine. 19, 100306.

3. Chatree, S., Sitticharoon, C., Maikaew, P., Pongwattanapakin, K., Keadkraichaiwat, I., Churintaraphan, M., Srip- 
Zaki, S. et al. / J. Appl. \& Nat. Sci. 13(3), 962 - 969 (2021)

ong, C., Sririwichitchai, R. \& Tapechum, S. (2021). Cissus quadrangularis enhances UCP1 mRNA, indicative of white adipocyte browning and decreases central obesity in humans in a randomized trial. Scientific Reports, 11, 2008 DOI:10.1038/s41598-021-81606-9

4. Chaudhari, R.L., Patil, P.S., Chaudhari, R.Y. \& Bhangale, J.O. (2013). Antihyperglycaemic activity of ethanolic extract of Cissus quadrangularis (L.) leaves in alloxan induced diabetic rats. Journal of Applied Pharmaceutical Science. 3, 73-77. DOI: 10.7324/JAPS.2013.30114.

5. Chinnadurai, G. S., Krishnan, S., Perumal, P (2018). Studies on detection and analysis of proteases in leaf extract of medicinally important plants. Phytomedicine, 40, 176-188. DOI:10.1016/j.phymed.2018.01.011

6. Chou C.T. (1997). The anti-inflammatory effect of Tripterygium wilfordii Hook F. on adjuvant induced paw edema in rats and inflammatory mediators release. Phytotherapy Research, 11, 152-154.

7. Cirillo, V.P. (1962). Mechanism of glucose transport across the yeast cell membrane. Journal of Bacteriology. 84, 485-491.

8. Deshpande, S.A., Carvalho, G.B., Amador, A., Phillips, A.M., Hoxha, S., Lizotte, K.J. \& Ja, W.W. (2014). Quantifying Drosophila food intake: comparative analysis of current methodology. Nature Methods, 11, 535-540. DOI: 10.1038/nmeth.2899

9. Dhanasekaran, S. (2020). Phytochemical characteristics of aerial part of Cissus quadrangularis $(L)$ and its invitro inhibitory activity against leukemic cells and antioxidant properties. Saudi Journal of Biological Sciences, 27, 1302-1309. DOI:10.1016/j.sjbs.2020.01.005

10. Edgecomb, R.S, Harth, C.E. \& Schneiderman, A.M. (1994). Regulation of feeding behavior in adult Drosophila melanogaster varies with feeding regime and nutritional state. The Journal of Experimental Biology, 197, 215-235.

11. Fejes, S., Blazovics, A., Lugasi. A., Lemberkovics, E., Petri, G. \& Kery, A. (2000). In vitro antioxidant activity of Anthriscus cerefolium L.(Hoffm) extracts. Journal of Ethnopharmacology. 69, 259-265. DOI: 10.1016/s0378-8741 (99)00171-3

12. Ghasemian, M., Owlia, S. \& Owlia, M.B. (2016). Review of anti-inflammatory herbal medicines. Advances in Pharmacological and Pharmaceutical Sciences. 2016. 9130979. DOI: 10.1155/2016/9130979

13. Gulati, V., Harding, I.H. \& Palombo, EA. (2012). Enzyme inhibitory and antioxidant activities of traditional medicinal plants: potential application in the management of hyperglycemia. BMC Complementary and Alternative Medicine. 12, 1472-1482. DOI: 10.1186/1472-6882-12-77

14. Harrison, M.E., Norris, M.L., Robinson, A., Spettigue, W., Morrissey, M., \& Isserlin, L. (2019). Use of cyproheptadine to stimulate appetite and body weight gain: A systematic review. Appetite, 137, 62-72. DOI: 10.1016/ j.appet.2019.02.012

15. Homnick, D.N., Homnick, B.D., Reeves, A.J., Marks, J.H., Pimentel, R.S. \& Bonnema, S.K. (2004). Cyproheptadine is an effective appetite stimulant in cystic fibrosis. Pediatric Pulmonology, 38, 129-134. DOI: 10.1002/ppul.20043

16. Howard, M.L., Hossaini, R., Tolar, C., \& Gaviola, M.L. (2019). Efficacy and Safety of Appetite-Stimulating Medications in the Inpatient Setting. The Annals of Pharmacotherapy, 53, 261267. DOI: $10.1177 / 1060028018802816$
17. Ilavarasan, R., Mallika, M. \& Venkataraman S. (2005). Anti-inflammatory and antioxidant activities of Cassia fistula Linn. bark extracts. African Journal of traditional, Complementary and Alternative Medicines, 2, 70-85. DOI: 10.4314/ajtcam.v2i1.31105

18. Iwueke, A.V., Nwodo, O.F. \& Okoli, C.O. (2006). Evaluation of the anti-inflammatory and analgesic activities of Vitex doinana leaves. African Journal of Biotechnology, 5, 1929-1935. DOI: 10.5897/AJB2006.000-5086

19. Jayaprakasha, G.K., Jena, B.S, Negi, P.S. \& Sakariah, K.K. (2002). Evaluation of antioxidant activities and antimutagenicity of turmeric oil: a byproduct from curcumin production. Zeitschrift fur Naturforschung. C, Journal of Biosciences, 57, 828-835. DOI: 10.1515/znc-2002-9-1013

20. Kelly, G.S. (1996). Bromelain: a literature review and discussion of its therapeutic applications. Alternative Medicine Review, 1, 405-410.

21. Kola, B., Farkas, I., Christ-Crain, M., Wittmann, G., Lolli, F., Amin, F., Harvey-White, J., Liposits, Z., Kunos, G., Grossman, A. B., Fekete, C. \& Korbonits, M. (2008) The orexigenic effect of ghrelin is mediated through central activation of the endogenous cannabinoid system. PLOS ONE, 3, e1797. DOI: 10.1371/journal.pone.0001797

22. Lekshmi, R.K. \& Mini, S. (2013). Evaluation of antioxidant and antiglycation activities of various solvent fractions of Cissus quadrangularis stem. International Journal of Pharma and Biosciences, 4, 1259-1268.

23. Levitt, A., \& O'Neil, J. (2018). Older Adults with unintended weight loss: The role of appetite stimulants. Home Healthcare Now, 36; 312-318. DOI: 10.1097/ $\mathrm{NHH} .0000000000000692$

24. McDonald, C.E. \& Chen, L.L. (1965). The Lowry modification of the Folin reagent for determination of proteinase activity. Analytical Biochemistry, 10, 175-177. DOI: 10.1016/0003-2697(65)90255-1

25. Mello, V.J., Gomes, M.T.R., Lemos, F.O., Delfino, J.L., Andrade, S.P., Lopes, M.T. \& Salas, C.E. (2008). The gastric ulcer protective and healing role of cysteine proteinases from Carica candamarcensis. Phytomedicine, 15: 237-244. DOI: 10.1016/j.phymed.2007.06.004

26. Mizushima, Y. \& Kobayashi, M. (1968). Interaction of antiinflammatory drugs with serum proteins, especially with some biologically active proteins. The Journal of Pharmacy and Pharmacology, 20, 169-173. DOI:10.1111/j.20427158.1968.tb09718.x

27. Muthu, S., Venkatesh Babu, G., Narayan, K.S., Prabu, S., Sathuvan, M., Mythileeswari, L., Nagaraj, S. \& Palani, P. (2017). Antibacterial cysteine protease from Cissus quadrangularis L. International Journal of Biological Macromolecules, 103, 878-888. DOI: 10.1016/j.ijbiomac.2017.0 5.107

28. Nabavi, S.M., Ebrahimzadeh, M.A., Nabavi, S.F., Fazelian, M. \& Eslami, B. (2009). In vitro antioxidant and free radical scavenging activity of Diospyros lotus and Pyrus boissieriana growing in Iran. Pharmacognosy Magazine., 4, 123-127.

29. Nematy, M., Kamgar, M., Mohajeri, S. M., Tabatabaei Zadeh, S. A., Jomezadeh, M. R., Akbarieh Hasani, O., Kamali, N., Vojouhi, S., Baghban, S., Aghaei, A., Soukhtanloo, M., Hosseini, M., Gholamnezhad, Z., Rakhshandeh, H., Norouzy, A., Esmaily, H., GhayourMobarhan, M., \& Patterson, M. (2013). The effect of hy- 
droalcoholic extract of Coriandrum sativum on rat appetite. Avicenna Journal of Phytomedicine, 3, 91-97.

30. Oguntibeju O.O. (2018). Medicinal plants with antiinflammatory activities from selected countries and regions of Africa. Journal of Inflammation Research, 11, 307 -317. DOI:10.2147/JIR.S167789

31. Otsuki, N., Dang, N.H., Kumagai, E., Kondo, A., Iwata, S., Morimoto, C., 2010. Aqueous extract of Carica papaya leaves exhibits anti-tumor activity and immunomodulatory effects. Journal of Ethnopharmacology, 127, 760767. DOI: 10.1016/j.jep.2009.11.024.

32. Rao, M., Sreenivasulu, M., Chengaiah, B., Reddy, K. \& Chetty, M. (2010). Herbal medicines for diabetes mellitus: A review. International Journal of PharmTech Research. 2: 1883-1892.

33. Rizvi, S.I. \& Mishra, N. (2013). Traditional Indian medicines used for the management of diabetes mellitus. Journal of Diabetes Research, 712092. doi.org/10.1155/20 $13 / 712092$

34. Sadique, J., Rqobah, A.I, Bughaith, M.F. \& El-Gindy, A.R. (1989). The bioactivity of certain medicinal plants on the stabilization of RBC membrane system. Fitoterapia, 60: 525-532.

35. Salehi, B., Ata, A., V Anil Kumar, N., Sharopov, F., Ramírez-Alarcón, K., Ruiz-Ortega, A., Abdulmajid Ayatollahi, S., Tsouh Fokou, P. V., Kobarfard, F., Amiruddin Zakaria, Z., Iriti, M., Taheri, Y., Martorell, M., Sureda, A., Setzer, W.N., Durazzo, A., Lucarini, M., Santini, A., Capasso, R., Ostrander, E.A., Sharifi-Rad, J. (2019). Antidiabetic potential of medicinal plants and their active components. Biomolecules, 9, 551. DOI: 10.3390/biom9100551

36. Sawangjit, R., Puttarak, P., Saokaew, S. \& Chaiyakunapruk, N. (2017). Efficacy and safety of Cissus quadrangularis L. in clinical use: A systematic review and metaanalysis of randomized controlled trials. Phytotherapy Research, 31, 555-567. DOI: 10.1002/ptr.5783

37. Sekhon-loodu, S. \& Rupasinghe, H. (2019) Evaluation of antioxidant, antidiabetic and antiobesity potential of selected traditional medicinal plants. Frontiers in Nutrition, 6: 53. DOI:10.3389/fnut.2019.00053

38. Shadmani, A., Rizwani, G. H., \& Ahmed, M. (2018). Potential anti-inflammatory effect of Cissus quadrangularis $\mathrm{L}$. and Lepedium sativum L. along with their combination extracts. Pakistan Journal of Pharmaceutical Sciences, 31, 2119-2122.

39. Shell, B.C., Schmitt, R.E., Lee, K.M., Johnson, J.C., Chung, B.Y., Pletcher, S.D., \& Grotewiel, M. (2018).
Measurement of solid food intake in Drosophila via consumption-excretion of a dye tracer. Scientific Reports, 8, 11536. DOI: 10.1038/s41598-018-29813-9

40. Siddiqui, S., Zia, Q., Abbas, M., Verma, S., Jafri, A., Misra, D., Luqmanm, S., Ahamed, M., Ahmad, M.S. \& Arshad, M. (2021). Antiproliferative activity of Cissus quadrangularis $\mathrm{L}$. extract against human cervical cancer cells: in vitro and in silico analysis. Anticancer Agents in Medicinal Chemistry, 2021. DOI: 10.2174/1871520621666 210210103729

41. Srisook, K., Palachot, M., Mongkol, N., Srisook, E., \& Sarapusit, S. (2011). Anti-inflammatory effect of ethyl acetate extract from Cissus quadrangularis Linn may be involved with induction of heme oxygenase- 1 and suppression of NF-kB activation. Journal of Ethnopharmacology, 133, 1008-1014. DOI: 10.1016/j.jep.2010.11.029

42. Staats, S., Luersen, K., Wagner, A.E. \& Rimbach, G. (2018). Drosophila melanogaster as a versatile model organism in food and nutrition research. Journal of Agricultural and Food Chemistry. 66, 3737-3753.

43. Stohs, S.J. \& Ray, S.D. (2013). A review and evaluation of the efficacy and safety of Cissus quadrangularis extracts. Phytotherapy Research. 27, 1107-1114.

44. Sundaran, J., Begum, R., Vasanthi, M., Kamalapathy, M., Bupesh, G. \& Sahoo, U. (2020). A short review on pharmacological activity of Cissus quadrangularis. Bioinformation. 16, 579-585. DOI: 10.6026/97320630016579

45. Syed, A.A., Reza, M.I., Husain, A., Singh, P. \& Gayen, J.R. (2021). Inhibition of NOX by Cissus quadrangularis extract protects from type 2 diabetes inducedsteatohepatitis. Phytomedicine Plus 1, 100021.

46. Tamil, I.G., Dineshkumar, B., Nandhakumar, M., Senthilkumar, M. \& Mitra, A. (2010). In vitro study on aamylase inhibitory activity of an Indian medicinal plant, Phyllanthus amarus. Indian Journal of Pharmacology. 42, 280-282. DOI: 10.4103/0253-7613.70107

47. Vijayalakshmi, A., Kumar, P.R., Priyadharshini, S.S. \& Meenaxshi, C. (2013). In vitro antioxidant and anticancer activity of flavonoid fraction from the aerial parts of Cissus quadrangularis (Linn.) against human breast carcinoma cell lines. Journal of Chemistry, 150675, 1-9. DOI: 10.1155/2013/150675

48. Zaki, S., Malathi, R., Latha, V. \& Sibi, G. (2020). A review on efficacy of Cissus quadrangularis in pharmacological mechanisms. International Journal of Clinical Microbiology and Biochemical Technology, 3, 49-53. 